\title{
PETROGRAPHIC AND PHYSICO-CHEMICAL CHARACTERISATION OF TAILINGS DUMP AND SOILS AROUND A NICKEL-COPPER MINING AND SMELTING ENVIRONMENT
}

GEORGES-IVO EKOSSE

(Received 8 July 2004; Revision accepted 4 November 2004)

\author{
ABSTRACT
}

Recent concerns of mining and smelting of nickel-copper ( $\mathrm{Ni}-\mathrm{Cu}$ ) in Selebi Phikwe, Botswana possibly affecting the environmental physico-chemistry motivated this study. Physico-chemical analyses which included particle size distribution (PSD), ph, electrical conductivity (EC), cation exchange capacity (CEC), color and descriptive petrography on samples of tailings dump and soils were performed in order to understand the significance of these properties on the surrounding physical environment. The PSO of soil samples revealed the average wh $\%$ of the $<2 \mu \mathrm{m}$ fraction (clay fraction) was between 3 and $9 \mathrm{w} \%$, the $: 2 \mu \mathrm{m}$ to $<50 \mu \mathrm{m}$ iraction (silt fraction) was between 34 and $44 \mathrm{wt} \%$ and the $>50 \mu \mathrm{m}$ to $<250 \mu \mathrm{m}$ traction (sand fraction) was between 47 and 63 W $\%$. Soil pH ranged from 3.5 to 6.0 . Electrical conductivily values were significanilly low, and the range was from $50 \mu S / \mathrm{cm}$ to $250 \mu \mathrm{S} / \mathrm{cm}$. Soils with low pH correspondingly had low EC and were close to the mine. The CEC values occurred between 2 meq/100 $\mathrm{g}$ and $20 \mathrm{meq} / 100 \mathrm{~g}$. Hand specimens of tailings dump viewed with a nicroscope and physical tests performed on the samples for hardness, cleavage, fracture, colour, streak, lustre, and crystal appearance depict albite, cristobalite, chaicopyrite, pyrnotite, tremolite, and pentlandite to be contained in them. Soil coloui varied from pale yeliow, reddish yellow to dark : zddish brown. Grains were pcurly sorted, with subangular grains located further from the plant, which is indicative of windblown particles transported at a short distance. Reddish brown solls were closer to the tailings dump, mining areas and the smelterfconcentrator plant. The observation is indicative of both $\mathrm{Fe}$ and $\mathrm{Cu}$ containing minerais enriching the soils of the siudy area. The findings of this study are indicative of increase in soil acidity due to mining and smelting of Ni-Cu at Selebi Phikwe area. High acidity favoured the 1. ching of heavy ions from tailings dump and related mining waste to the soils. Fewer exchange sites have resulted in a low CEC for ions adsorbed on the sediment surfaces, consequently they remain in solution and are bioavailabe for plant uptake.

KEYWORDS: tailings dump; soils; physicorchemistry; particle size distribution; petrography; environment

\section{INTRODUCTION}

Nickel-copper. (Ni-Cu) has been mined in Selebi Phikwe, Botswana since 1956, and it is suspected that the mining and smelting activities are having an effect on the immediate physical environment.

Previous studies of Ni-Cu orebodies (Nkoma and Ekusse, 1999; 2000) and soils (Ekosse et. al., 2003), and particulate air matter (Ekosse et. al., 2004) conducted on different samples obtained within the Selebi Phikwe area indicated mineral constituencies that reflected the presence of heavy metals emanating mainly from mining and smelting activities. Furthermore, studies on environmental chemistry of the Selebi Phikwe area depicted trends in heavy metals concentrations in soils and Colophospermum mopane (Ekosse et. al., 2004a) to L. similar to those obtained for imbrasia belina in the same study area (Ekosse et. al., 2004b) which were all related to the mining activities there.

However, no work has so far been reported on in literature regarding the petrographic and physico-chemical aspects of the tailings dump and soils surrounding the Selebi Phikwe NiCu mining and smelting environment. In this study, an attempt was made to link information on mineralogy of the transition sulphide minerals from the ore bodies (Nkoma and Ekosse, 2000). to the physico-chemical characteristics of the tailings dump and soils around the Selebi Phikwe Ni-Cu mine area, Botswana. The primary objective of this stud; was to petrographically and physico'chemically characterise the tailtngs dump and soils in order to understand how mining and smelting activities affect the physico-chemistry of the environment

\section{MATERIALS AND METHODS}

\section{Study Area}

Selebi Phikwe is one of the urbanized townships of Botswana, rated after Gaborone, Francistown, Maun, and Lobatse Grant and Grant, 1995). The study area is located in the northeastern part of the country between longitudes $27^{\circ} 47^{\prime} \mathrm{E}$ and $27^{\circ} 53^{\prime} \mathrm{E}$, and latitudes $22^{\circ} 55^{\prime} \mathrm{S}$ and $22^{\circ}$ OO'S (Figure 1 ).

\section{Samples and Sampling}

Samples for laboratory analyses were obtained from ten sites, of which nine were in the study area (Figure 2), and th: tenth site being the control site located $56 \mathrm{~km}$ from the study area (Table 1). Fourteen sampling trips were made, and during each sampling trip, three representative samples were chosen. Of the three representative samples, two were obtained close to the sides and one was taken from the centre of the tailings dump, making a total of 42 tailings dump samples collected for analyses. A hand shovel and a trowel were used to oblain the samples. Sampling was done at about $5 \mathrm{~cm}$ from the surface of the tailings dump mount

Random (Jewell et. al., 1993) and judgmental (Crepin and Johnson, 1993) sampling techniques were used in obtaining soil samples from the ten sampling sites. One hundred and forty samples were. collected for analyses: Grab soil samples (Tan, 1996), were obtained by shallow sampling techniques using a machete, a trowel and/or a shovel. Samples were taken at a depth of between $0 \mathrm{~cm}$ and $20 \mathrm{~cm}$. Both samples of tailings dump and soils were put in an oven at $60^{\circ} \mathrm{C}$ overnight to allow moisture to escape.

\section{Laboratory Analyses}

Granulometric Analyses

The particle size (PS) and particle size distribution (PSD) of snil samples were determined in two stages: the first stage was using a mechanical/electrical shaker with a nest of sieves, and the second stage was using an automatic particle size analyzer (PSA). The principle of operation is based on Stoke's law of sedimentation of individual spherical particles falling freely at a steady velocity under the influence of gravity, 


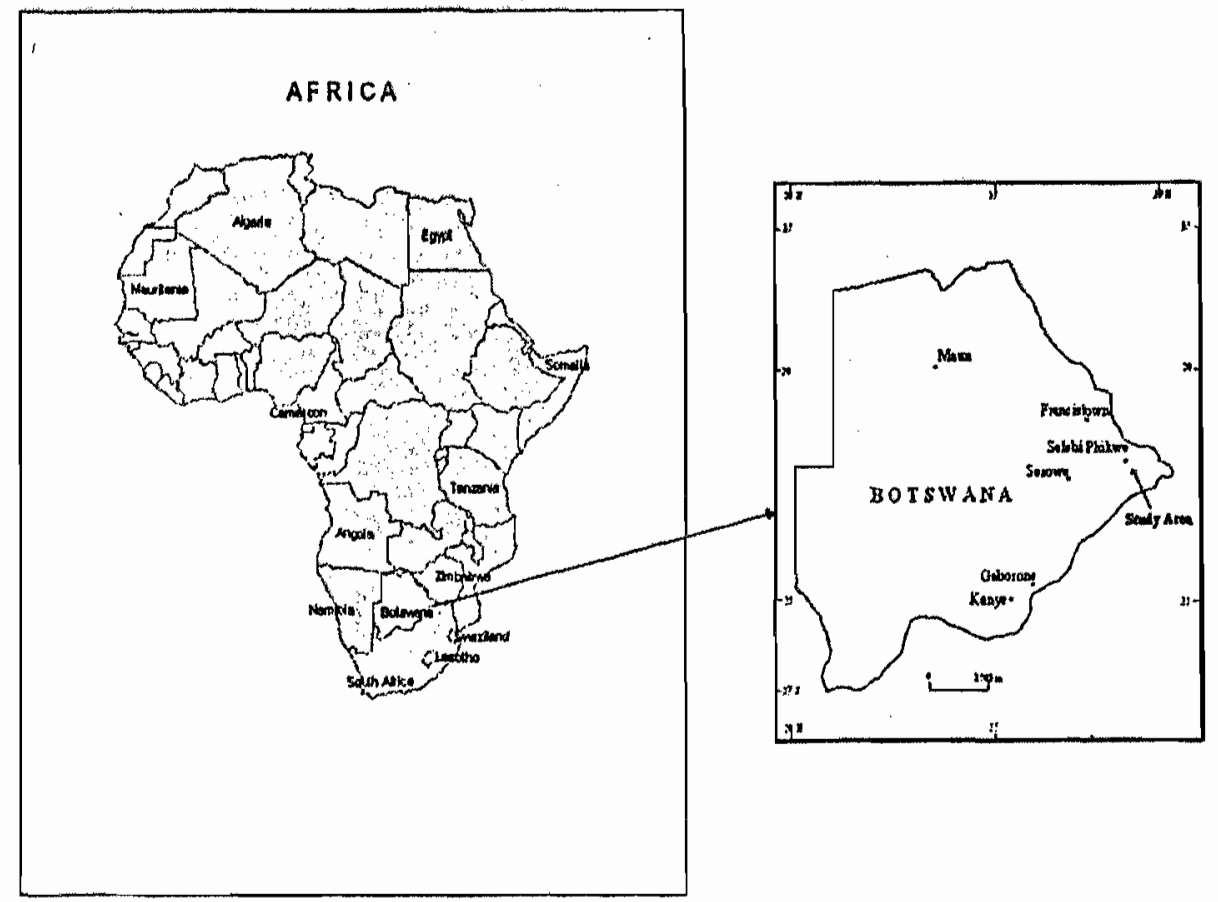

Figure 1: Map of Africa indicating Botswana, and of Botswana showing where Selebi

Phikwe is located

Table 1: Location/Characteristics of sampling sites at the Selebi Phikwe-township area

\begin{tabular}{|c|l|}
\hline Sampling site & \multicolumn{1}{|c|}{ Location/Characteristics } \\
\hline 1 & $\begin{array}{l}\text { Industrial area (150 m after the railway } \\
\text { crossing) } \\
\text { Bosele Hotel (Commercial area) and new } \\
\text { township }\end{array}$ \\
\hline 3 & $\begin{array}{l}\text { Between the township stadium and the } \\
\text { mine (behind the Botswana Power } \\
\text { Corporation, BPC) }\end{array}$ \\
\hline 4 & $\begin{array}{l}\text { Between the Township boundary and the } \\
\text { railway line (directly behind a Community } \\
\text { Junior Secondary School, CJSS) }\end{array}$ \\
\hline 5 & $\begin{array}{l}\text { Opposite the Mine hospital, close to old } \\
\text { township }\end{array}$ \\
\hline 7 & $\begin{array}{l}\text { Between the mine and explosive storage } \\
\text { facilities (close to old township) }\end{array}$ \\
\hline 8 & $\begin{array}{l}\text { Towards the airport (about 250 m from the } \\
\text { Airport-Sefophe-Selebi Phikwe Road } \\
\text { juncture) }\end{array}$ \\
\hline 10 & $\begin{array}{l}\text { Off untarred road leading to the Selebi } \\
\text { North mine (100 m out of township } \\
\text { boundary, adjacent to the new township) }\end{array}$ \\
\hline 9 & $\begin{array}{l}\text { Off last but one bridge before entering into } \\
\text { the Selebi Phikwe lownship }\end{array}$ \\
\hline $\begin{array}{l}\text { Control site localed close to the road } \\
\text { juncture leading to Selebi Phikwe from the } \\
\text { Gaborone-Francistown main road }\end{array}$ \\
\hline
\end{tabular}

resisted only by the viscous drag of the medium (Gaspe et. al., 1994), and is mathematically expressed as:

$$
V=\left[2 r^{2}\left(d_{p}-d_{w}\right) g\right] / 9 \eta
$$

where $V=$ rate of settling of particles $\left(\mathrm{cms}^{-1}\right), r=$ radius of particles $(\mathrm{cm}), d_{p}=$ density of liquid medium $\left(\mathrm{gcm}^{-3}\right), a_{w}=$ density of water $\left(\mathrm{gcm}^{-3}\right), \eta=$ coefficient of viscosity (poise) $\left(\mathrm{gcm}^{-1} \mathrm{~s}^{-1}\right)$ and $\mathrm{g}=$ acceleration due to gravity $\left(981 \mathrm{sec}^{-2}\right)$.

The mechanical/electrical shaker was set at 60 strokes per minute (spm), and the nest of sieves consisted of the following particle size ranges in $\mu \mathrm{m}: 500,425,355,300,250,180,150$. 125,106 , and 53 . The $<53 \mu \mathrm{m}$ size fraction of surface sediments samples were analyzed using the 1993 model Shimadzu SA-CP4 automatic particle size analyzer (PSA). The analyzer was set at 240 revolutions per minute (rpm). The particle sizes were automatically measured by the PSA.

\section{Descriptive Petrography and Color Determination}

Tailings dump and soil samples for descriptive petrography and color determination were aerated for 24 hours. Clayey aggregates were separated using a mortar and pestle to single jarticles. With a spatula, the samples were mounted on white cardboard sheets provided by the Munsell Color Company Inc., MD 21218, USA. The color descriptions, which comprise the hue, value/chroma and color of the mounted samples, were obtained by visually comparing them to those of standard surface sediments recorded in the Munsell Soil Color book (1992). Optical microscopy technique was used for descriptive analyses of the tailings dump and the non-clay fraction of the surface sediments. A Leitz Ortholux II Pol-BK petrographic microscope was used for the analyses.

\section{The $\mathrm{pH}$ and Electrical Conductivity}

Van Reeuwijk (1993), Okalebo et al. (1993) and Barnard et. al. (1990) ciescribed the methods for $\mathrm{pH}$ and EC analysis of soils. Finely ground/pulverized soil samples were used for $\mathrm{pH}$ and $\mathrm{EC}$ determination. Aliquots of $2.5 \mathrm{~g}$ of sample were placed in three centrifuge tubes and suspended in $25 \mathrm{ml}$ of distilled $\mathrm{H}_{2} \mathrm{O}$. After shaking on a horizontal shaker for about 30 minutes, the tubes were centrifuged for five minutes. Average values were calculated and recorded for each sample analyzed. The $\mathrm{pH}$ and $E C$ of the supernatant of the samples were analyzed with a Jenway $3020 \mathrm{pH}$ meter and a Jenway 4020 EC meter. The temperature of the samples at the time of analyses was recorded. 
2tsor

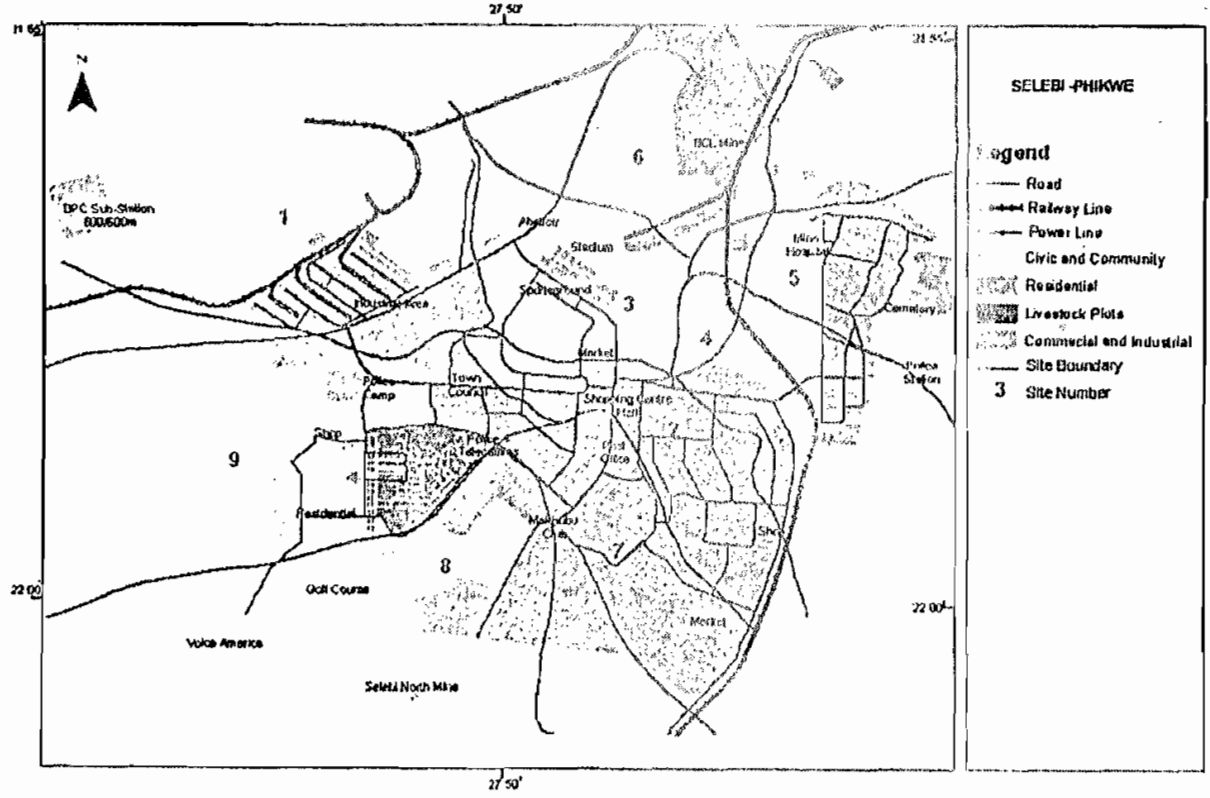

Figure 2: Map of Selebi Phikwe showing the diffe:ent sampling sites

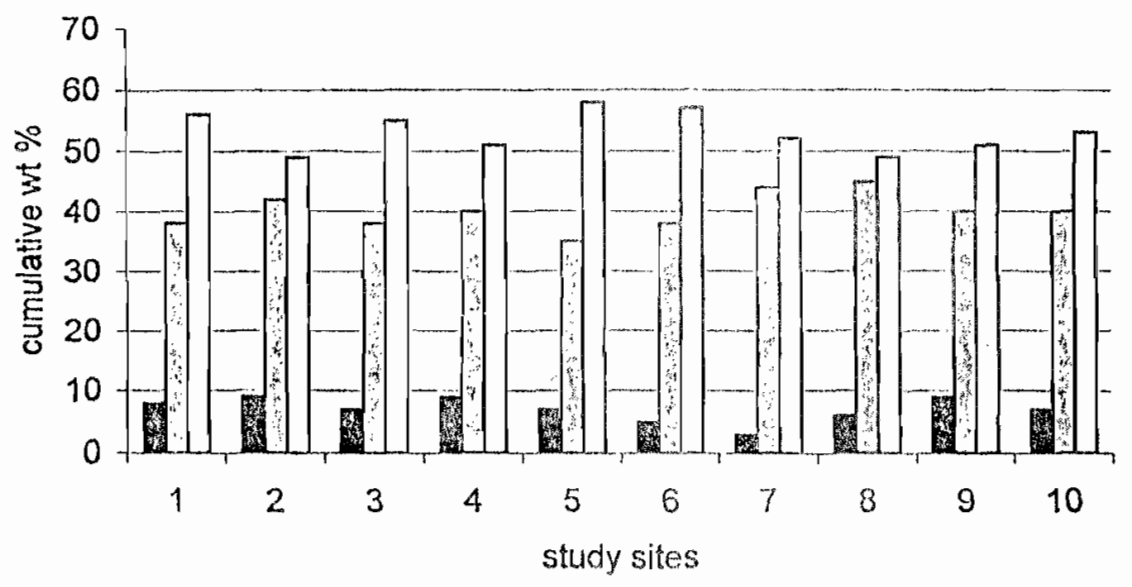

Figure 3: Mean cumulative wt $\%$ of clay, sill and sand fractions of samples. (Note that

for cach study site in the figure, the first bar is for clay, the second is for silt and the

third is for sand).

Analysis of Exchangeable Cations

The CEC of the surface sediments was determined using the barium chloride-triethanolamine $\left(\mathrm{BaCl}, 2-\mathrm{CH}_{3}-\mathrm{CH}_{2} \mathrm{OH}\right)_{3} \mathrm{~N}$ method which is described in Inglethorpe et. al., (1993), and also described in Ma and Eggleton (1999). Five grams of soi? sample were put in $100 \mathrm{ml}$ centrifuge and buffered with $\mathrm{BaCl}_{2}$ for an hour with four or five stirrings periodically. The centrifuge tube was set to make 30000 rounds at $2000 \mathrm{rpm}$ After centrifuging, the supernatant was decanted and an additional $100 \mathrm{ml}$ of $\mathrm{BaCl}_{2}$ added. All the unabsorbed ions of Ba were washed off using deionized water. $100 \mathrm{ml}$ of $0.05 \mathrm{M}$ $\mathrm{MgSO}_{4} .7 \mathrm{H}_{2} \mathrm{O}$ was added to each of the weighed contents in the tube and the mixture was allowed to react for at least two hours. Centrifuging of the mixture was done for another hour. and $10 \mathrm{ml}$ of the supernatant was collected into a $100 \mathrm{ml}$ conical flask. Twelve drops of $1 \mathrm{M} \mathrm{NH}$ of $\mathrm{SG} 0.91$ and six drops of catechol violet indicator were added to the suspension, which was titrated with $0.02 \mathrm{M}$ Di-Na EDTA. The CEC was calculated from the titrant values.

\section{RESURTS}

Granulomatric Analyse:

Based on the classification: scheme of particle sizes for the Association Internationale Pour Les Etudes d'Argiles (AIEA) (intemational Association for Study of Clay Mincubls), Whicies that are $\leq 2 \mu \mathrm{m}$ in euhedral spherical diameter (esd) are classified as chay, paricles that are $>2 \mu \mathrm{m} \leq 50 \mu \mathrm{m}$ are taken to be sili, and particles $>50 \mu \mathrm{m} \leq 250 \mu \mathrm{m}$ are considered to be sand. Particles $>250 \mathrm{\mu m}$ were discarded because their mineralogy is mainly grain quartz which does not affect the chemistry of the surface environment (Kralik, 1999).

The distibution pattern of soil particles showed an afparent homogeneity within the study area, althogh slight variations were detected. The mean $w t \%$ for the soil samples occurred at hemeen $100 \mathrm{~km}$ and $120 \mathrm{\mu m}$. Average trend of distribution of porsiato: revolon day fraction to be between 3 and 9 wt \% 
Table 2: Descriptive petrography of minerals conlained in tailings dump from the Selebi Phikwe Ni-Cu orebodies.

\begin{tabular}{|c|c|c|c|c|c|c|c|}
\hline Mineral & $\begin{array}{l}\text { Hard-ness } \\
\text { (Mohr scale) }\end{array}$ & Cleav age & Fracture & Color & Streak & Lustre & $\begin{array}{l}\text { Crystal } \\
\text { appearance }\end{array}$ \\
\hline Aclinolite & $5-6$ & Good & $\begin{array}{l}\text { Uneven to } \\
\text { subconchoid }\end{array}$ & $\begin{array}{l}\text { Light to } \\
\text { plackish } \\
\text { green }\end{array}$ & White & Vilteous & Monoclinic \\
\hline Albite & $6-6.5$ & Distinct & Uneven & $\begin{array}{l}\text { White } 10 \\
\text { colorless }\end{array}$ & White & $\begin{array}{l}\text { Vitreous } \\
\text { to pearly }\end{array}$ & Triclinic \\
\hline Cristobalite & 7 & None & Conchoidal & $\begin{array}{l}\text { Color-tess to } \\
\text { gray }\end{array}$ & White & Vitreous & Tetragonal \\
\hline Chalcopyrite & $3.5-4$ & Poor & $\begin{array}{l}\text { Uneven to } \\
\text { conchoidal }\end{array}$ & $\begin{array}{l}\text { Brassy } \\
\text { yellow }\end{array}$ & $\begin{array}{l}\text { Green to } \\
\text { black }\end{array}$ & Metallic & Tetragonal \\
\hline Malachite & $3.5-4$ & Good & Uneven & $\begin{array}{l}\text { Emerald } \\
\text { green }\end{array}$ & $\begin{array}{l}\text { Light } \\
\text { green }\end{array}$ & $\begin{array}{l}\text { Vitreous } \\
\text { to silky }\end{array}$ & Monoclinic \\
\hline Pyrite & $6-6.5$ & $\begin{array}{l}\text { None } \\
\text { distinct }\end{array}$ & $\begin{array}{l}\text { Conchoidal } \\
\text { to uneven }\end{array}$ & Pale yellow & $\begin{array}{l}\text { Green } 10 \\
\text { black }\end{array}$ & Metallic & Cubic \\
\hline Pyrthotite & $3.5-4.5$ & None & $\begin{array}{l}\text { Uneven to } \\
\text { subconchoid } \\
\text { al }\end{array}$ & $\begin{array}{l}\text { Bronze } \\
\text { yellow }\end{array}$ & $\begin{array}{l}\text { Dark gray } \\
\text { to black }\end{array}$ & Metallic & Hexagonal \\
\hline Tremolite & $5-6$ & Good & $\begin{array}{l}\text { Uneven } 10 \\
\text { subconchoid } \\
\text { al }\end{array}$ & $\begin{array}{l}\text { Colorless } \\
\text { white }\end{array}$ & White & Vitreous & Monoclinic \\
\hline Pentlandite & $3.5-4$ & None & $\begin{array}{l}\text { Uneven to } \\
\text { conchoidal }\end{array}$ & $\begin{array}{l}\text { Light bronze } \\
\text { yellow }\end{array}$ & $\begin{array}{l}\text { Bronze to } \\
\text { brown }\end{array}$ & Metallic & Isometric \\
\hline
\end{tabular}

with a mean of $7 w t \%$, silt portion to be between 34 and $44 w t$ $\%$ with a mean of 39 wt \%, and sand portion between 47 and 63 wt $\%$ with a mean of 51 wt $\%$. The wt $\%$ of clay size fraction along study sites was almost uniformly distributed as revealed in Figure 3. The mean PSD curves of soils from the ten sites are given in Figure 4. Sites two, four and nine were the most clayey sites with mean average of $9 \mathrm{wt} \%$. These sites were conse to water runways and a stream (site nine) where leaching of ions for clay mineral formation was prevalent. Clay contents in sites six, seven, and eight were less than the mean wl. \% of clay at the study area. The $7 \mathrm{wt} \%$ of clay in soil samples from sites three, five and ten corresponded to the mean wt \% of clay fraction at the study area.

Ther sittiest samples were from sites two, seven and eight with values. which approached $44 \mathrm{wt} \%$, whereas the least silty samples were from site five with 35 wt \% as indicated in Figure 3. The: sites where the siltiest samples were found were located near gravelled motorways where particle reworking had been promoted by traffic as well as other factors, such as wind, rain and topography. The silt fraction obtaineu from soil samples at sites one, four, nine and ten were consistent and approximated at $40 \mathrm{wt} \%$. The values for silt fraction from sites three and six exceeded $35 w \%$ but were below 40 wt \%. Sites five and six shown in Figure 4, were the most sandy and site two was the least sandy, with a value of $47 \mathrm{wt} \%$. All other sites had mean values of their sand fraction to between $48 \mathrm{wt}$ $\%$ and $58 \mathrm{wt} \%$. Trends in sandiness of surface sediments samples deviated slightly from trends for silt and clay fractions of the samples.

\section{Descriptive Petrography and Color Determination}

Hand specimens viewed with a microscope and physical tests performed on the samples for hardness, cleavage, fracture, color, streak, lustre, and crystal appearance depicted albite, cristobalite, chalcopyrite, pyrrhotite, tremolite, and pentlandite in the samples. Small, dark and brassy yellow pseudotetragonal crystals of chalcopyrite and acircular green films of malachite could visibly be detected as mineral constituents of the tailings dump.

Actinolite, $\quad \mathrm{Ca} 2(\mathrm{Mg}, \mathrm{Fe})_{5} \mathrm{Si}_{8} \mathrm{O}_{22}(\mathrm{OH})_{2} ;$ albite. $\mathrm{NaAlSi}_{3} \mathrm{O}_{3}$; cristobalite, $\quad x-\mathrm{SiO}_{2} ; \quad$ chalcopyrite, CuFes; $\mathrm{C}_{2} ;$ malachite $\mathrm{Cu}_{2}\left(\mathrm{CO}_{3}\right)(\mathrm{OH})_{2} ;$ pyrite, $\mathrm{FeS}_{2}$; pyrrhotite, $\mathrm{Fe}_{(1-x)} \mathrm{S}$; tremolite $\mathrm{Ca}_{2} \mathrm{Mg}_{5} \mathrm{Si}_{8} \mathrm{O}_{22}(\mathrm{OH})_{2}$; and pentlandite $(\mathrm{Fe}, \mathrm{Ni})_{9} \mathrm{~S}_{8}$ were identified and have been described as observed petrographically in rable 2. Hand specimen of the tailings dump samples, observed by using a hand lens, showed sub-angular quartz grains and crystals of grayish green amphiboles. These mineralogical observations are in conformity with previous work (Nkoma and Ekosse, 1999; 2000).

The quartz grains of surface sediments were poorly sorted and were subangular at the sites close to the smelter/concentrator plant. Further away from the plant where wind blown fiuvially deposited particles were found, the grains were well sorted, semi-rounded to round. When observed under the microscope, the surface sediments were generally semi-rounded to rounded with low to high sphericity in shape. The quartz grains, which constituted part of the surface sediments, were angular to subangular with high sphericity.

The surface sediments had varied color distribution pattern ranging from.pale yellow, reddish yellow to dark reddish brown. A summary of the surface sediments color according to the study sites is given in Table 3. The surface sediments from siles four, five, six and seven were light colored compared to those from the other sites. Whitish gray to reddish gray

Table 3: Color distribution pattern of representative surface sediments samples from the sites of the Selebi Plikwe study area.

\begin{tabular}{c|c|c|l}
\hline Site Number & Hue & Value/Chroma & \multicolumn{1}{c}{ Culor } \\
\hline 1 & $7.5 \mathrm{YR}$ & $5 / 8$ & Strong brown \\
\hline 2 & $5 \mathrm{YR}$ & $3 / 4$ & Dark reddish brown \\
\hline 3 & $10 \mathrm{R}$ & $6 / 3$ & Pale red \\
\hline 4 & $7.5 \mathrm{YR}$ & $7 / 6$ & Reddish yellow \\
\hline 5 & $10 \mathrm{YR}$ & $7 / 6$ & Yellow \\
\hline 6 & $10 \mathrm{YR}$ & $8 / 3$ & Very pale brown \\
\hline 7 & $7 \mathrm{YR}$ & $7 / 6$ & Reddish yellow \\
\hline 8 & $10 \mathrm{YR}$ & $8 / 4$ & Very pale brown \\
\hline 9 & $10 \mathrm{YR}$ & $3 / 4$ & Dark reddish brown \\
\hline 10 & $10 \mathrm{YR}$ & $3 / 1$ & Very dark gray \\
\hline
\end{tabular}


precipitates were found on soils close to the smelter/concentrator plant. In areas where surface sediments were tinted with whitish gray precipitates, the strong smell of sulphur was detected, and there was no vegetation cover. At sites nine and ten, the surface sediments were dark reddish brown and very dark gray; dark color being influenced from organic matter deposition resulting from decayed plants and fluvial activities. Cement, sand and concrete formed an integral part of the surface sediments at the control site

\section{The pH and Electrical Conductivity}

The average $\mathrm{pH}$ and $\mathrm{EC}$ values at ambient temperature, for the soil obtained from all the sampling sites are given in Figure
5. The $\mathrm{pH}$ values ranged from 3.5 to 9.0 . Slightly basic to basic $\mathrm{pH}$ values were obtained from surface sediments from sites seven, eight, nine and ten. The $\mathrm{pH}$ values obtained for samples from sites three, four five and six were prominently lower than those for samples from other sites of the study area.

The samples obtained from the ten sites of the study area were grouped into three based on their EC values. Samples from sites four and five had EC values, which were $<50 \mu$ $\mathrm{Scm}^{-1}$. Samples obtained from sites one, two, seven, eight and nine had $\mathrm{EC}$ values $\geq 50 \mu \mathrm{Scm}^{-1} \leq 150 \mu \mathrm{Scm}^{-1}$. The third group of samples was obtained from sites three, six and ten and had $\mathrm{EC}$ values $\geq 100 \mu \mathrm{Scm}^{-1} \leq 250 \mu \mathrm{Scm}^{-1}$.

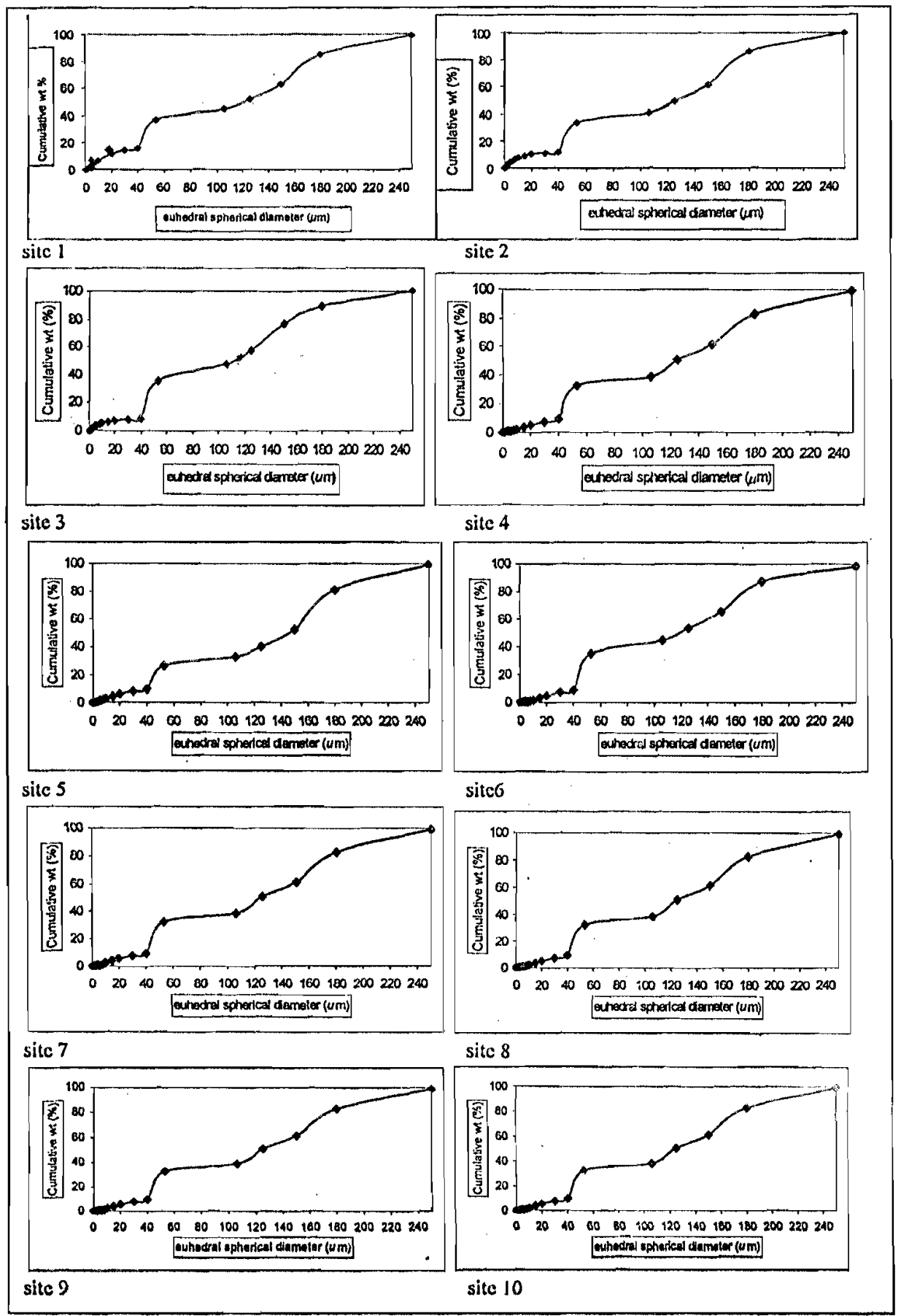

Figure 4: Mean cumulative frequency distribution of representative soil samples from the study sites 


\section{Cation Exchange Capacitance}

The CEC values of the soil samples were between 2 meq/100 $\mathrm{g}$ and 20 meq/100 $\mathrm{g}$ (Figure 6), which is typical of $1: 1$ clay minerals that are found dominantly in kaolinitic surface sudiments. The mineral content of the soils could have included minor/trace quantities of 2.1 clay minerals such as smectite and illite. It should be pointed out that the soils from site eight had a remarkably low CEC; with an average value of 52 meq/100 $\mathrm{g}$. The soils from sites one, three and six had CEC values slightly higher than $15 \mathrm{meg} / 100 \mathrm{~g}$.

The average CEC value for site one was 20 meq/100 g, site three was 16 meq $/ 100 \mathrm{~g}$ and site six was $17 \mathrm{meq} / 100 \mathrm{~g}$. With low $\mathrm{pH}$ values and high CEC values for soils from site six, it is likely that acidification could have taken place significantly more compared to other sites of the study area.

\section{DISCUSSION}

\section{Grabulometric Influence on the Environment}

The pSO of soil samples revealed the $<2 \mu \mathrm{m}$ fraction (clay fraction) to be in the range of 3 and $9 \mathrm{wt} \%$, the $>2 \mu \mathrm{m}$ to $<50$ $\mu m$ fraction (silt fraction) was between 34 and $44 \mathrm{wt} \%$, and the $=50 \mu \mathrm{m}$ to $<250 \mu \mathrm{m}$ fraction (sand fraction) was between 47 and $63 \mathrm{wt} \%$. This observed uniformity of PSO created equal opportunity for ions of heavy metals to migrate and to adhere to the clay fraction; thereby promoted similar soil contamination trends. Distance of source of contaminants may. have played a major role at determining the quantitative aspects of the contaminants in the soils. Grains were poorly sorted, with subangular grains located further from the plant, which is indicative of windblown particles transported at a short ristance (Ringrose et. al., 1995). Finer particles from the tailings dump could be windblown to distant environments, and eventually affect the ecosystem.

Environinental Aspects of Descriptive Petrology and Color The grains of tailings dump observed at Selebi Phikwe were subangular, depicting limited transportation from source (Bain et. al., 1995), and also indicative of less aggressive leaching activities taking place (Singh et. al., 1999): Mineral ore bodies and tailings dump release particles to the atmosphere through convectional forces with wind energy as vector agent (Buseck and Posfai, 1999). Smelting processes release gases. Most significant are wastes released from tailings dump into the s'rface sediments, which eventually influence the concentrations of heavy metals contained in living organisms (Kozák et. al., 1995). Due to the fact that tailings dump are main sources of acid nine drainage (AMD) (Galan el. al, 1999), adequate control measures are necessary in limiting the spread of contaminants in the surrounding environments.
The steps obviously taken by the mining authorities in containing their tailings dump are in conformity to basic principles of environmental management of tailings dump as described to by Galan et al. (1999), and Jambor and Bowles (1998).

The color of soils reflects Fe content (Dixon, 1989), which is contained in pyrite and pyrrhotite (Nkoma and Ekosse, 1999; $2000\}$. Color changes influence variation in mineral and chemical compositions of the soils (Tan, 1996). Whitish gray sediments in some soil samples were due to precipitation from saturated ions of dissolved salts rich in heavy metals (Robertson et. al. 1997; Shaw et. al., 1998). In these environments, the surface sediments were deprived of vegetation cover and dead zones formed. Remaining aggregates used during road construction, which were not removed from the area, have weathered, and might also have influenced surface sediments color at the control site.

Influence of pHt and Electrical Conductivity on the Environment.

The $\mathrm{pH}$ of soils ranged from 3.5 to 9.0 with very acidic soils located close to the smelter/concentrator plant. The low pH values at these sites (three, four, five and six), could be attributed to their closeness to the smelter/concentrator plant, the tailings pond and the tailings dump where very high concentrations of $\mathrm{SO}_{4}{ }^{2-}, \mathrm{Cd}, \mathrm{Co}, \mathrm{Cr}, \mathrm{Cu}, \mathrm{Fe}^{2+}, \mathrm{Ni}, \mathrm{Se}$, and $\mathrm{Zn}$ as described by Bowles et. al, (1998), occur. Very high concentrations of $\mathrm{Fe}^{2+}$ and $\mathrm{SO}_{4}{ }^{2+}$ increase acidity in the environment, and there is the tendency of acid expansion due to probable depletion of the acid-neutralizing capacity of the soils (Shaw et. al., 1998). Eventually, the $\mathrm{pH}$ values at sites seven, eight, nine and ten could drop as the surrounding soils are contaminated with heavy metals.

High acidity could favour the leaching of heavy ions from the railings dump and related mining waste to the soils. High acidity of soils is reflected by on-going acid mine drainage (AMD) activity which is depicted by areas of poor or no vegetation cover and are referred to as dead zones (HantongFong et. al., 1997). A similar phenomenon occurred at the $\mathrm{Ni}$ mine area, near Sudbury, Ontario, Canada (Hantong-Fong et. al., 1997). Low pH of soils, furthermore, could promote the leaching and precipitation of ions including those of heavy metals namely $\mathrm{Cd}, \mathrm{Co}, \mathrm{Cr}, \mathrm{Cu}, \mathrm{Fe}, \mathrm{Ni}$, Se and $\mathrm{Zn}$. The pyrrhotite $\left(\mathrm{Fe}_{7} \mathrm{~S}_{3}-\mathrm{FeS}\right)$ and pyrite $\left(\mathrm{FeS}_{2}\right)$ in the tailings dump as explained by Holmström and Öhlander (1999) and HolmstrÖm et al. (1999), are oxidised on exposure to water to form sulphate and sulphuric acid

Electrical conductivity values obtained for the soil samplès

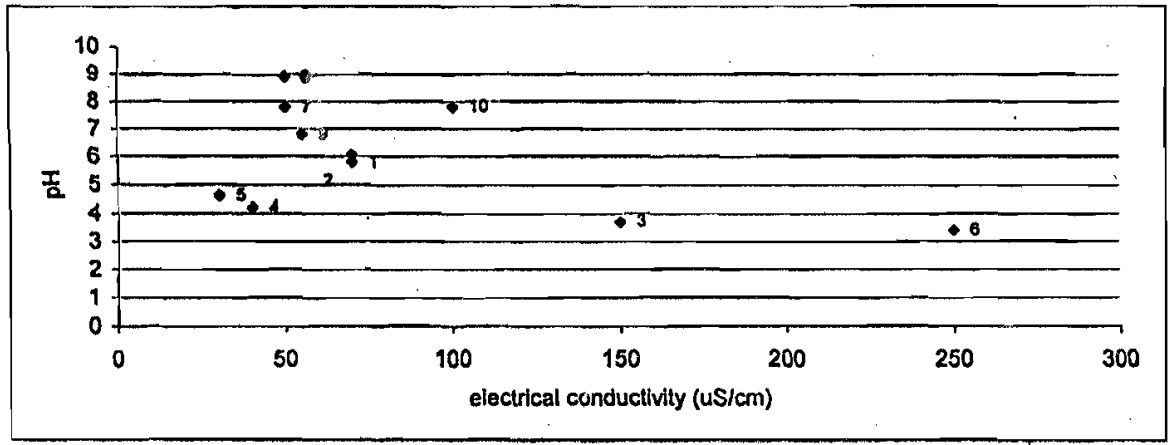

Figure 5: Average $\mathrm{pH}$ and electrical conductivity values of whole surface sediments

samples from the different sampling sites at the Selebi Phikwe area. (Note numbers in

graph depict sampling sites). 


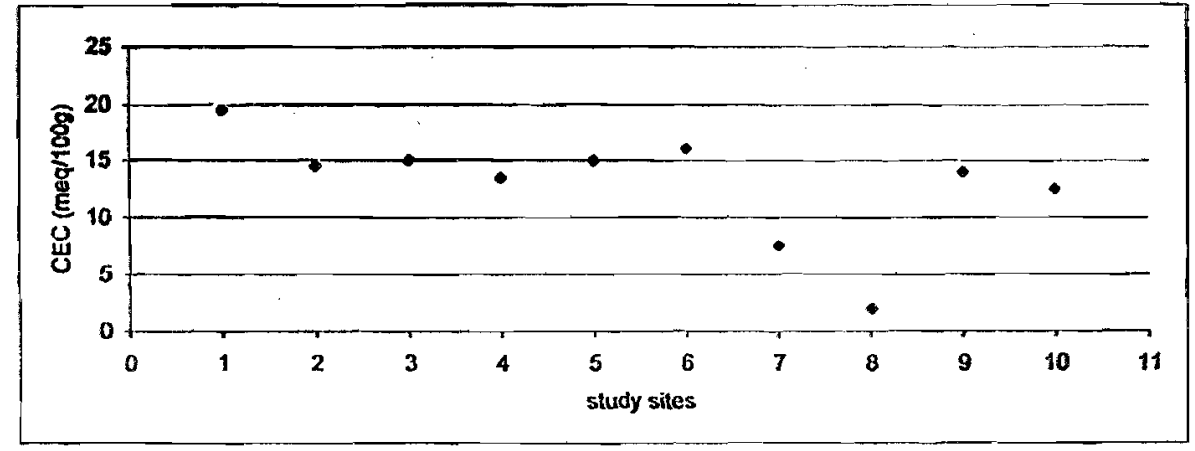

Figure 6: Avcrage values of $\mathrm{CEC}$ of whole surface sediments samples from the

\author{
different sampling sites at the Selebi Phikwe area.
}

were significantly low, and ranged from $50 \mu \mathrm{s} \mathrm{cm}^{-1}$ to $250 \mu$ $\mathrm{Scm}^{-i}$. The amount of total dissolved solids (TDS) in soils can be estimated from their EC values (Murray, 1986). The EC is used to estimate the presence of dissolved salts such as sulfates, carbonates, phosphates and chlorides. The TDS of given sample may not be reflected by its $\mathrm{pH}$ because the salts are generally neutral. Solls with low pH correspondingly had low EC.

The rocks become acidic in a low $\mathrm{pH}$ environment, leading to precipitation of ions including those of heavy metals. Py, hotite ( $\left.\mathrm{Fe}_{7} \mathrm{~S}_{9}-\mathrm{FeS}\right)$ and pyrite $\left(\mathrm{FeS}_{2}\right)$ in tailings dump are oxidized on exposure to water to form sulphate and sulphuric acid as indicated in equations 2 and 3 (Al et. al., 1994; 1994a; Benner et. al., 1997; Bowles et. al., 1995)

$2 \mathrm{FeS}_{2}+16 \mathrm{H}_{2} \mathrm{O} \rightarrow 2 \mathrm{FeSO}_{4}+2 \mathrm{H}_{2} \mathrm{SO}_{4}+14 \mathrm{H}^{+}$

$4 \mathrm{FeSO}_{4}+1 \mathrm{OH}_{2} \mathrm{O}+\mathrm{O}_{2} \rightarrow 4 \mathrm{Fe}(\mathrm{OH})_{3}+4 \mathrm{H}_{2} \mathrm{SO}_{4}$

The acidification reactions could be accelerated by the bacterium Thiobacillus ferroxidans, the absence of neutralizing minerals such as calcite $\left(\mathrm{CaCO}_{3}\right)$, and release of heavy metals into their ionic state (Bowles et. al., 1998). Piles of tailings durnp stay for years probably without proper disposal. During

stuckfiling, ions of heavy metals leached into the soils and water bodies, and could eventually be absorbed by plants.

Inffuence of Cation Exchange Capacity on the Environment.

T:L CEC values for soil samples obtained were between 2 meq $100 \mathrm{~g}^{-2}$ and $20 \mathrm{meq} 100 \mathrm{~g}^{-1}$. These values are typical for kaolin mimerals intercalated with smectites in soils (Dixon, 1999). Samples with high EC also contained illite. Finer clayey particles tend to adsorb heavy ions of elements on their sufaces as demonstrated by Song et al. (1399). In the soil samules, fewer exchange sites resulted in a low CEC for jons adsorbed on the surfaces of the soil particles, consequently they remained in solution and are bioavailabe for plant uptake.

Vaicies obtained for CEC at the study area reffected cation exchange sites for ions of heavy metals to either have been adsorbed on the surface of clay mineral structure, or absorbed by isomorphous substitution. Whereby heavy metal ions are either adinered on or absorbed into the clay mineral structure. the surface sediments were contaminated with the corresponding heavy metals, and eventually got polluted.

\section{CONCLUSIONS}

This study has attempted to petrographically and physicoc:emically characterise the tailings dump and soils surrounding a $\mathrm{Ni}-\mathrm{Cu}$ mining and smelting environment in
Botswana. The primary objective was to establish any irfiuence on the environmental physico-chemistry as a result of mining/smelting activities. Physico-chemical analyses which included particle size distribution (PSD), $\mathrm{pH}$, electrical conductivity (EC), cation exchange capacity (CEC), color and descriptive petrography on samples of tailings dump and soils were performed in order to understand the significance of these properties on the surrounding physical environment.

Results depicted in-put of contaminants from tailings dump and mining/smeiting activities to the soils. High acidity of sois is reflected by on-going acid mine drainage (AMD) activity which is depicted by the formation of dead zones. Pyrrhotite ( $\left.\mathrm{Fe}_{7} \mathrm{~S}_{8}-\mathrm{FeS}\right)$ and pyrite $\left(\mathrm{FeS}_{2}\right)$ in lailings dump are oxidized on exposure to moist environments forming sulphate and sulphuric acid. Fewer exchange sites have resulted in a low CEC for ions adsorbed on the surfaces of soll particles: consequently they remain in solution and are bioavalabe for plant uplake.

\section{REFERENCES}

Al, T. A., Bowles, D. W. and Jambor, J. L., 1994. The porewater geochemistry of the $\mathrm{CH}-\mathrm{Zn}$ mine tailings at Kidd Creek, near Jimmins, Ontario, Canarda. Paper presented at the International land reciannation and mine Drainage Cosfercunce and the $3^{\text {nty }}$ lontemationa? Conference on the abatement of acid mine drainage held 24-29 April, 1994, Pittsburgh, PA. USA, 10 pp.

Al, A. T., Bowles, D. W. and Jambor, J. L., $1994 \mathrm{~s}$. The geochemistry of mine-waste pore water affected by the combined disposal of natrojarosite and basenaetal sulphide tailings at Kidd creek. Timmins, Ontario, Can. Geotech. Jounn. 31: $502-512$.

Bain, J. G., Bowles, O. W. and Robertson. W. D., 1995. The hydrogeochemistry of a sand aquifer affected by discharge from the nickel Rim tailings, Sudbury, Ontario. Paper presented at the Conference on Mning and the environment, Sudbury. Ontario. 28 May-1 June, 1995.

Barnard, R. O. Buys, A. ע., Coetzee, J. G.K. "Du Freez, C

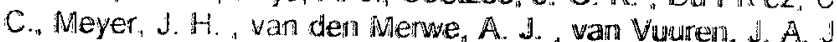
and Volschenk, J. E., 1990. Handbook of standard soil testing methods for advisory purposes. Soil Science Sociely of South Africa, Pretoria. $120 \mathrm{pp}$

Benner, S. G., Bowles, D. W. and Ptacek, d., 1997. A full scale porous reactive wall for prevention of acid mine drainage, Ground Water Monitoring an id inediation. 17: 99-107. 
Bowles, D. W., Al, T. A., Lorite, L., Gould, W. D. and Jambor.

J. L., 1995. Microbiological, chemical, and mineralogical characterisation of the Kidd Creek Min Tailings Impoundments, Timmins area, Ontario, Geomicrobiology Journ. 13: 13-31.

Bowles, D. W., Jambor, J. L. and Hantong-Fong, C. J. , 1998. Geochemical, mineralogical and microbiological characterisation of a sulphide-bearing carbonate-rich gold-mine tailings impoundment, Joutel, Quebec, Applied Geochemistry 13:687.705.

Buseck, P. R. and Posfai, M., 1999. Airborne minerals and related aerosol particles: Effects on climate and the environment. Colloquium paper presented at the National Academy of Sciences on Geology. Mineralogy, and Human Welfare, Held Nov 8-9, 1998. Arnold and Mabel Beckman Centre, Irvine, CA. USA., 96: 3372-3379.

Crépin, J. and Johnson, R. L. , 1993. Soil sampling for environmental assessment. In: R. M. Carter (Editor) Soil sampling and methods of analyses.

Department of Town and Regional Planning, 1996. Selebi Phikwe Development Plan. Selebi Phikwe Town Council. $55 \mathrm{pp}$.

Dixon. J. B., 1989. Kaolin, serpentine group minerals. In: Dixon J. B. (Editor) Minerals in the environment. $2^{\text {nd }}$ Edition. SSSA 1: $467-523$

Ekosse, G., van clen Heever, D., de Jager, L. and Totolo, O., 2003. Environmental mineralogy of soils around the Selebi Phikwe Ni-Cu mine area, Botswana. The International Journal of Environmental Studies, 60: 251-262

Ekosse, G., Van den Heever, D. J.; de Jager L., and Totolo,

O., 2004. Environinental chemistry and mineralogy of particulate air matter around Selebi Phikwe copper-nickel plant, Botswana. Minerals Engineering. 17: 349-353

Ekosse, G., Van den Heever, D. J., de Jager L., and Totolo, O. 2004a. Mineralogy of tailings durap around Selebi Phikwe nickel-copper plant. Botswana. Journal of Applied Science and Environmental Management 8: 37-44

Ekosse, G., Van den Heever, D. J., de Jager L., and Totolo, O., 2004b. Heavy metals concentrations in Imbrasia belina (phane caterpillar) around the Selebi Phikwe Ni-Cu mine and srnelter/concentrator plant, Botswana. International Conference on Environmental and Health Aspects of Mining. Refining and Reláled Industries. Kasane, Botswana June 27 - July 1, 2004

Galan, E. Carretero, M. I and Fernandez-Caliani, J. C., 1999. Effects of acid mine drainage on clay minerals suspended in the Tinto River (Rio Tinto, Spain), An experimental approach, Clay Minerals 34: 99-108.

Caspe., A., Messer, P. and Young P., 1994. Clay testing. A manual on clay/non-clay measuring technique. Intermediate Technology Publications. $17 \mathrm{pp}$.

Grant, S. and Grant, E., 1995. Decorated homes in Botswana. Phuthadikobo Museum, Mocludi, Botswana. $134 \mathrm{pp}$.

Hantong-Fong, C. J. Bowles, .D. W. and Stuparyk, R. A., 1997. Evaluation of low sulphur tailings in the prevention of acid mine drainage. $4^{\text {th }}$ International Conference on acid mine drainage, Vancouver, B. C. Canada 31 May-6 June, 1997. Conference Proceedings 2: 835 847.

HolmstrÖm, H., Ljungberg. J. and Öhlander, B. , 1999. Role of carbonates in mitigation of metal release from mining waste. Evidence from humidity cclls tests. Environmental Geology. 37: 276-280.

Holmström, H. and Öhlander, B., 1999. Oxygen penetration and subsequent reactions in flooded sulphidic mine tailings: a case study at Stekenjokk, northern Sweden, Applied Geochemistry 14: 747-759.

Inglethorpe, S. D., Morgan, D. J., Highley, D. E. and Bloodworth, A. J., 1993. Industrial minerals laboratory manual: Bentonite. British Geological Survey Technical Report WG/93/20. $116 \mathrm{pp}$.

Jambor, J. L. and Bowles, D. W., 1998. Major-element variations in the reactive sulphide-rich tailings at the Waile Amulet Mine site, Noranda area, Quebec, Canada, American institute of Mining Eng. Process Mineralogy 9: 511-523,

Jewell, M.C., Hensley, P. J., Barry, D.A. and Acworth, I., 1993. Site investigation and monitoring techniques for contaminated sites and potential waste disposal sites. In: R. Fell, T. Philips, C. Gerrad, (Editors) Geotechnical management of waste and contamination.

Kozàk, J., Janku, J. and Jehlicka, J., 1995. The problems of heavily polluted soils in the Czech Republic: A case study. In: Salmons W., Fröstener U. and Mader P. (Editors) Heavy metals: Problems and solutions. Springer. 287-300

Kralik, M., 1999. A rapid procedure for environmental sampling and evaluation of polluted sediments. Applied Geochemistry. 14, 807-816.

Ma, C. and Eggleton, R. A., 1999. Cation exchange capacity of kaolinite. Clays and Clay Minerals. 47: 174-180.

Munsell Soil Colour Book, 1992. The Munsell soil colour book. Colour charts". Munsell Colour Company Inc., MD 2128, USA.

Murray. H. H., 1986. Clays. Ullmann's Encyclopedia of Industrial Chemistry. Weinheim. $5^{\text {th }}$ Edition. 109-136.

Nkoma, J. S. and Ekosse, G., 1999. X-ray diffraction study of chalcopyrite $\mathrm{CuFeS}_{2}$, penttandite $(\mathrm{Fe}, \mathrm{Ni})_{\mathcal{S}} \mathrm{S}_{4}$ and pyrrhotite $\mathrm{Fe}_{1-x} \mathrm{~S}$ obtained from $\mathrm{Cu}-\mathrm{Ni}$ ore bodies. Journal of Physics: Condensed Matter. 11, 121-128.

Nkoma, J. S. and Ekosse, G., 2000. X-ray powder" diffraction study of transition sulphide minerals contained in $\mathrm{Ni}$ $\mathrm{Cu}$ orebodies from Selebi Phikwe; southeastern Botswana. Botswana Notes and Records. 32: 165176

Okalebo, J. R., Gathua, K. W. arid Woomer, P. L., 1993. Laboratory methods of soil and plant analysis. A working manual. Soil Sc. Soc. East Afr. Tech Public $1: 1-88$.

Ringrose, S., Sefe F. and Ekosse, G., 1995. Progress towards the evaluation of desertification in Botswana, Desertification Control Bulletin, 27: 62 - 68 . 
riobertson, W. D., Bowles, D. W. and Hanton-Fong. C. J., 1997. Sulphide oxidation related to water table depth at two Sudbury, Ontario tailings impoundments of different physiography. $4^{\text {th }}$ International conference on acid Rock drainage held at Vancouver, B. C. on 31 May 6 June, 1997. Conference Proceedings 11: 621-629.

Shaw, S. C., Groat, L. A., Jambor, J. L., Bowles, D. W., Hantong-Fong, C. J. and Stuparyk, R. A., 1998. Mineralogical study of base metal tailings with various sulphide contents, oxidised in laboratory columns and field lysmeters, Environmental Geology 33: 209-217.

Singh, A. K., Hasnain, S. I. and Banerjee, D. K., 1999. Grair: size and geochemical partitioning of heavy metals in sediments of the Damodar River - a tribulary of the lower Ganga, India, Environmental Geology, 39: 9097.
Song, Y., Wilson, M. J., Moon, H. S., Bacon, J. R. and Bain.

D. C., 1999. Chemical and mineralogical forms of lead, zinc and cadmium in particle size fractions of some wastes, sediments and soils in Korea, Applied Geochemistry.14: 621-633.

Tan, K. H., 1996. Sample preparation. In: M. Dekker (Editor) Soil sample preparation and analysis, $14 \mathrm{pp}$.

Van Reeuwijk, J., 1993. Procedures for soil analysis. Int. Soil Ref and Info Center, Wageningen. The Netherlands, Tech Paper 9,100 pp. 